\title{
Playing in the Ruins of Arnhem: Reenacting Operation Market Garden in Theirs Is the Glory
}

\author{
László Munteán
}

Films determine our popular image of World War II. When we remember the Battle of Britain, the Battle of the Bulge, and the D-Day landings, we do so through the spectacular battle scenes and memorable acting performances in Guy Hamilton's Battle of Britain (1969), Ken Annakin's The Battle of the Bulge (1965), and Steven Spielberg's Saving Private Ryan (1998). Operation Market Garden, the air and ground offensive carried out by the allied forces in the Netherlands in September 1944, is no exception: A Bridge Too Far (1977, Attenborough), a threehour-long blockbuster, has played a key role in introducing the ill-fated operation into the collective memory of World War II. Although eclipsed by the immense success of Star Wars (1977, Lucas), its cast of international superstars, lavish scale, and superb marketing earned Attenborough's film the recognition it enjoys today. As a result, the very first cinematic representation of Operation Market Garden, Brian Desmond Hurst's Theirs Is the Glory, released in 1946, faded into oblivion for decades to come. Apropos of recent commemorations of the campaign the film has been brought back into the limelight (Smith 2010). However, apart from William B. Travis's (1986) comprehensive article on the making of the film and a few websites dedicated to Hurst's work and the history of parachute regiments, the film has not received serious scholarly attention.

What makes Theirs Is the Glory unique among war films is that it features veterans of the First British Airborne Division. Having fought at Arnhem in September 1944, many of the veterans returned a year later to reenact the battle. The result is a film that seamlessly combines original newsreel with reenactment, shot in the style of a feature film. Such an eclectic mix of genres, as well as shooting on location without professional actors, led one of the first reviewers of the film to point out its lack of "cinematic virtues" (K.F.B. 1946, 135). A recent blog likewise criticizes the unprofessional quality of acting as one of the film's major shortcomings (Lloyd 2014). ${ }^{1}$ Indeed, the artificiality of dialogues, in addition to the

1 Lloyd maintains that in Hurst's film “[ $t$ ] he soldiers are obviously not actors, and don't do very good jobs of portraying themselves. They tend to speak in stilted sentences in that very blasé British way, in which men in terrible peril seem not at all concerned about it. It gets so silly

(C) LÁSZLÓ MUNTEÁN, 2018 | DOI 10.1163/9789004292017_006

This is an open access chapter distributed under the terms of the prevailing CC-BY-NC License at the time of publication. 
poor quality of explosions, makes it difficult for the viewer to follow the plot. These cinematic flaws are, however, not only distracting. Paradoxically, they are key to the captivating power of Hurst's production.

Despite the absence of such cinematic virtues as realistic acting and special effects Theirs Is the Glory is a captivating film to watch even today. This essay argues that these very limitations are part and parcel of the way in which the film engages with and memorializes what was then the very recent past. The argument of this essay is twofold. First, through the analysis of acting and mise-en-scène it demonstrates that the film derives its power less from its realistic depiction of the Battle of Arnhem and more from the veterans as authentic witnesses and the ruins as authentic imprints of the battle. Second, it explores how the film employs this aura of authenticity as a rhetorical platform to re-imagine and embed the unsuccessful campaign within the larger trajectory of the liberation of the Netherlands.

\section{Retrieving the Lost Object}

This section undertakes a detailed analysis of the opening of Theirs Is the Glory, which sets the rhetorical tone for the rest of the film. Within this time frame of seven and a half minutes a veritable array of texts, voices, images, and music is employed to position the film vis-à-vis the historical event, as well as the viewer vis-à-vis the film and, by extension, the historical event. These rhetorical devices fall into five distinct modes: an authenticating mode, a commemorative one, a grateful, a strategic and a personal one. An analysis of these modes is helpful to uncover the affective dimension of rhetoric, the techniques Hurst applies to create an emotional disposition towards the failed operation.

Before the opening music starts, a text entitled "Foreword" appears against a dark background: “'Theirs Is the Glory' has been produced entirely without the use of studio sets or actors. Every incident was either experienced or witnessed by the people who appear in the film" (n.p.). This information is at once selfreflexive and performative. It is self-reflexive because, rather than foregrounding history as a narrative context within which the film is set, it calls attention to the production of the film itself. By way of sharing information about the lack of sets and actors, the foreword establishes a spatiotemporal bond between the people that appear in the film and the historical event they experienced. In terms of C.S. Peirce's system of signs, this bond is an indexical one insofar

it reminded me of that scene in Monty Python's 'Life of Brian' in which an English soldier is mildly perturbed by a tiger biting off his leg" (2014). 
as the sign and its referent engage in an existential relationship, not unlike the one that exists between a foot and a footprint $(1955,106)$. Consequently, everything that we are about to see in the film is, in one way or another, an indexical sign of Operation Market Garden. The information disclosed in the foreword also constitutes a performative statement in J.L. Austin's (1962) sense. The indexical relationship established between the historical event and the people and locations that appear in the film operates as an authenticating force in that it renders the film an interface between the viewer and the people that "witnessed or experienced" the battle.

This performative gesture is carried over by the text that appears next. Once the foreword fades into a cloudy sky the insignia of the First British Airborne Division, the Pegasus and Bellerophon, appears and a longer text rolls down slowly, accompanied by the ceremonious tone of brass instruments in Guy Warrack's soundtrack:

It was in September 1944 that the men of the First British Airborne Division made their heroic stand at Arnhem. One year later survivors returned to the actual battlefield amid the ruins of Arnhem truthfully to re-enact and record for all time this most gallant action in which they had gained the admiration even of the enemy. This film is a tribute to every man who fought at Arnhem and an everlasting memorial to those who gave their lives. (n.p.)

While the foreword posits the witness as an imprint of the historical event, this text supplements that claim by ascribing the quality of truthfulness to the reenactment of the battle, which is to be recorded for posterity. The word "record," however, occludes directorial voice and grants agency to the veterans' reenactment as a guarantee of faithful representation. Played by a brass ensemble, the march-like melody of the soundtrack is more solemn than upbeat and more ceremonious than celebratory. As a musical background to the text, it accentuates the sentiment of commemoration, articulated in the last sentence.

The sentiment of the last sentence, which renders the film a tribute and memorial, signals a shift from the authenticating to the commemorative mode, which culminates in the film's title appearing in Blackletter, with the airborne insignia lingering in the background. By way of ascribing glory to the veterans and declaring the film a memorial the text demands that viewers watch the film with reverence and respect. Thus, the commemorative mode takes its performative power from the authenticating rhetoric of the previous sentences that posit the veteran as an indexical imprint of the past. It is through the commemorative mode, however, that this past is made meaningful in the present. 
The film's title bears testament to the effort to overwrite the painful memory of a lost campaign with a narrative centered on "this most gallant action," thus foregrounding gallantry as a moral standard against which the operation is to be measured.

In his discussion of reenactment in documentary films Bill Nichols contrasts the "classic documentary image - where an indexical link between image and historical occurrence exists" with actual reenactment, where such an indexical connection is absent $(2008,74)$. The fact that the reenactment is temporally removed from the event that it represents burdens it with what Nichols regards as its "impossible task ... to retrieve a lost object in its original form even as the very act of retrieval generates a new object and a new pleasure" $(2008,74)$. Nichols's formulation of the desire to conjure the specter of a "lost object" is triply poignant in the case of Theirs Is the Glory. First, it marks the effort to reverse the passage of time and revisit the bygone event. Second, it entails the attempt to briefly reclaim the lives that have been lost during the operation. Third, it connotes the outcome of the battle as a military failure. It is in this third instance that the performative power of the commemorative mode most lucidly comes to the fore. "To make good that loss," to adopt Nichols' words, is to reclaim control over the campaign that got out of control a year before and, with hindsight, inscribe the battle into the trajectory leading to allied victory $(2008,74)$.

The scene that unfolds after the opening words creates a fantasmatic realm for investing the battle with meaning within a larger narrative framework. The film's title gradually fades into an image of Arnhem's pre-war riverfront, which turns out to be a painting as the camera zooms out. The solemn music that accompanied the text gives way to the quiet tunes of string and woodwind instruments, lending an idyllic feel to the town. These tunes also serve as a background for the voice of an invisible narrator, marked by his Dutch accent and speaking in first person plural, on behalf of the local population. His description of the peaceful town hit by the fury of war is echoed by the painting of the riverfront changing into panning shots of war-torn buildings and crosses erected in a haste to mark the graves of English soldiers. As the camera tracks over the bridge that the British troops were trying to hold, the narrator recalls "those brave men of the sky who came lightly equipped as airborne troops must, to fight for fortyeight hours, and then fought day after day against the tanks and heavy weapons of the Huns" (n.p.). The narrator next describes such landmark locations of the battle as St. Elizabeth Hospital, the village church at Oosterbeek, and the Hartenstein Hotel, where the last stand was made. The last shot in the sequence of locations shows a farmer plowing his field with a wooden cross in the foreground, covered with a soldier's helmet—a juxtaposition of symbolic images of war and peace, accompanied by the narrator's closing words: "And now, as 
time does its best to cover the scars of war, the people of the soil make ready for a new harvest and the sons of British homes might rest and a free world may live" (n.p.). The Dutch accent that marks the voice of the liberated is a rhetorical device that underpins the causal relationship forged visually between the sacrifice of the airborne troops and the liberation of the Netherlands (Figure 1). Word and image together constitute what Nichols calls a "mise-en-scène of desire," where defeat is resignified as a token of freedom $(2008,76)$.

This "grateful" mode, in which the disembodied Dutch narrator gives thanks for the sacrifice of the British soldiers, sets the stage for the following scene in which the pastoral image of the countryside in the wake of the war changes into a miniature model of Arnhem observed by military officials. Brass instruments again take the lead in the soundtrack as the plan of Operation Market Garden, explained by an invisible narrator speaking with a British accent, is laid out on a map. Archival footage of the briefing of the troops and final preparations at an English airfield are interspersed with the map revealing the bridge at Arnhem as the key location of the campaign. This is the first time that original footage turns smoothly into reenactment, with Lieutenant Hugh Ashmore briefing his regiment in front of a map of Arnhem (Smith 2010). Ashmore, who was commanding officer of the 3 rd Platoon of the 21 st Independent Parachute Company, here plays Lieutenant Hanbury, a fictional platoon commander

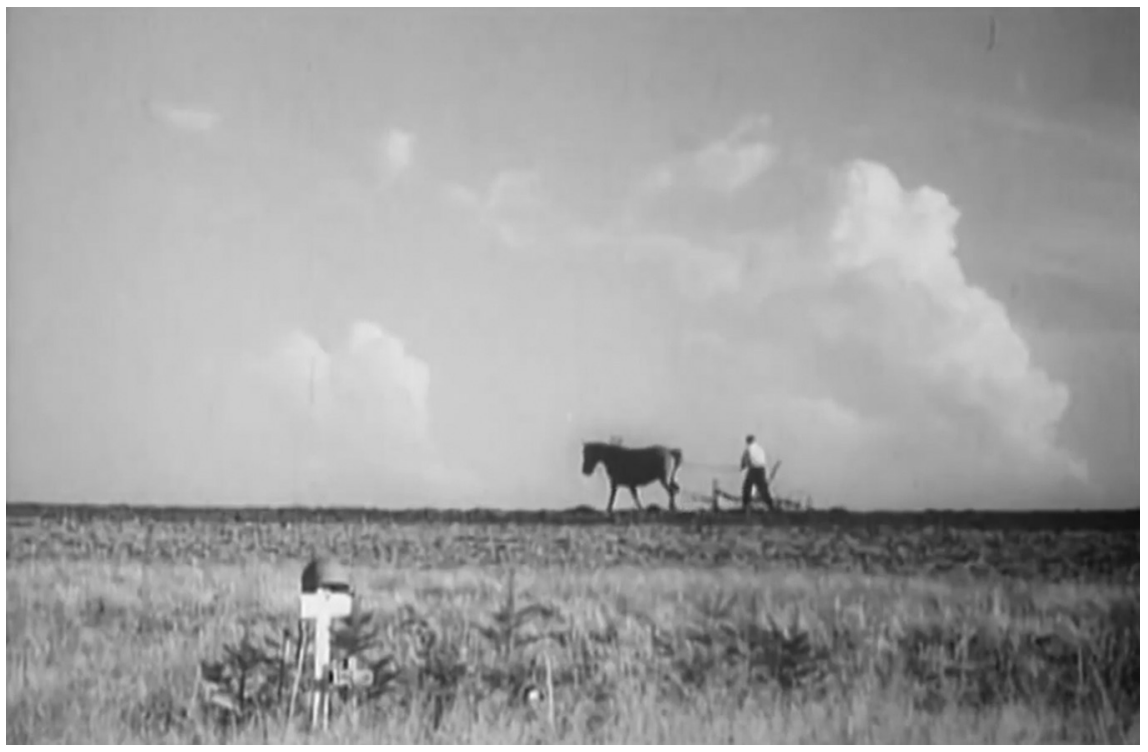

FIGURE 1 Framing the sacrifice of airborne troops as the precondition for peace. Screenshot from Theirs Is the Glory. 
(Travis 1986, 32). The viewer is taken back to England, prior to the offensive, this time looking at Arnhem on the map, through the eyes of the military strategist. The grateful words of the Dutch narrator invest this strategic mode with a teleological dimension that contextualizes the battle within the larger trajectory of the liberation of the Netherlands. The reenactment of the sermon delivered during the mass before the takeoff gives this trajectory a religious underpinning. The priest declares that "we are, in some mysterious measure, God's instruments and we are called to right believers' wrongs" (n.p.). The mission thus framed grants angelic power to the paratroopers, prefigured by the Dutch narrator's reference to "those brave men of the sky" (n.p.).

A preceding scene, which takes place immediately after Ashmore's briefing session, serves as a rhetorical counterpoint to the representation of the troops as crusaders. In it, ten men are shown in their barracks lying in bed, getting ready for their final rest before the operation. "Paratroopers aren't supermen. These, for all the deeds they accomplished, are just ordinary people” (n.p.), says the narrator. Then he introduces the men by name and job, situating them within the peaceful lives they left behind. The slow pan over the soldiers rhymes with the camera movement employed at the church service but operates in a different affective register. The latter homogenizes the soldiers, wearing their uniform and listening to the sermon. The former places them in the context of the limited privacy they enjoyed as individuals of diverse geographical and occupational backgrounds. By doing so, this portrayal offers a screen for a fantasmatic identification not simply with the soldiers as "ordinary people," but also with the imaginary of peacetime Britain delineated by the biographical details of these airborne soldiers. At film's end the same sleeping quarters are shown with two surviving soldiers brooding over the empty beds of their deceased comrades (Travis 1986, 37). ${ }^{2}$ The distant echo of biographical details from the film's beginning is gently absorbed by words delivered in the commemorative mode, reminiscent of Simonides's epigram dedicated to the fallen Spartans at Thermopylae: ${ }^{3}$

They have written in letters of fire an immortal page of history. Their manner of passing should be carried like a banner borne high by all that come after. Their story will be told wherever men cherished deeds of good report. The story of those filthy, grimy, wonderful gentlemen who drop from the clouds and fight where they stand. Just ordinary men. (n.p.)

2 Travis speculates that the eight empty beds signify the eight thousand soldiers who died, while the two sitting on their beds represent the two thousand that survived $(1986,37)$.

3 The epigram reads: "Go tell the Spartans passerby, that here obedient to their laws we lie." 
In her work entitled Performing Remains Rebecca Schneider argues that reenactment renders the past "a future direction in which one can travel" (2011, 22). By declaring the absence of actors and studio prop-ups in the production Hurst foregrounds the veterans as authentic agents of reenactment the truthfulness of which is predicated on their indexical connection to the battle. The rhetorical embedding of the battle into the narrative of liberation can be described as a "fantasmatic project" in Nichols's sense where the pleasure of retrieving the lost object is guaranteed by the viewer's (as well as the soldiers') retrospective knowledge of allied victory (Nichols 2008, 76). The last words, "just ordinary men," recall the narrator's introduction of the soldiers as "just ordinary people." Mentioned again at the end of the film, the word "ordinary" works as a euphemism. For it is by celebrating these men as extraordinary that Theirs Is the Glory shifts attention from military failure to heroic sacrifice and thus sets the stage, rhetorically, for what the viewer is about to see.

Of the five rhetorical modes outlined in the previous section the one that authenticates the reenactment is key to the affective register sustained throughout the film. Deploying the veteran as participant and witness is to convey the presence of the past corporeally, as it were. But does authenticity also warrant realism? The fact that reenacted parts in the film are often mistaken for original war footage and have inadvertently been used in documentaries (Hughes 2012, 209) indicates that certain reenacted scenes are so realistic that it is hard to tell them apart from contemporary newsreel. This applies particularly to establishing shots, capturing locations at a distance. ${ }^{4}$ Other shots create the opposite effect. A number of commentators have complained about the veterans' bad acting as counterproductive to the film's narrative power. Indeed, once the original footage of the preparations changes into the briefing of the soldiers by Hugh Ashmore, it becomes evident that his authentic presence as a veteran has little to do with the quality of his acting. His monotonous and quick pace of talking betrays that he recites a text he has learned. At one point he even looks into the camera by accident, leaving no doubt that, despite his presence as a veteran, he is out of his element as an actor. In addition, he does not reenact his own role in the campaign but plays a fictitious character.

When Hurst decided to have veterans reenact the Battle of Arnhem in his film, he was drawing on preexisting conventions of documentary filmmaking, while also breaking new ground. Using reenactment in documentaries was already well established in his time. The film that comes closest to the way in which Theirs Is the Glory features veterans is Dutch filmmaker Joris Ivens's

4 Although he does not reference Hurst's film, Nichols sees such combinations of reenactment and documentary footage as ethically untenable $\left(2008,73^{-74}\right)$. 
1934 silent documentary Borinage. In it, Ivens addresses the plight of a miners' community in Wallonia and has local coal miners reenact a march they organized a year before. Eventually, the reenactment reinforced their sense of community and rekindled the miners' indignation at their exploiters, which granted a degree of realism to the film (Nichols 2001, 149-151). Ivens makes no secret about his stance against capitalism and his political identification with the miners, which he conveys through propagandistic intertitles, informing viewers of rising unemployment, deprivation, and solidarity among the poor against the rich. Yet the referent of reenactment in Borinage is not so much a past event as it is an expression of present fervor that made the miners' performance so convincing. In the absence of sound, however, this realism is played out on the visual level. ${ }^{5}$ Theirs Is the Glory features a similar reenactment of the recent past but it allows the reenactors to be heard, so to speak, through staged conversations. Although parts of Hurst's film can indeed be mistaken for combat footage, the audiovisual exposure of veterans, as Ashmore's briefing of the soldiers attests, generates the opposite effect.

By preparing the viewers for an authentic reenactment and simultaneously withholding the pleasure of realism Hurst indeed runs the risk of losing his audience. This is not to say, however, that Borinage succeeds in doing justice to the miners' cause while Theirs is the Glory fails to pay proper tribute to the veterans. On the contrary. The less successful the veterans' acting, the more they come to the fore as witnesses and survivors. The realistic reenactment in Ivens's film generates a sense of presence, a reclaiming of the lost object in Nichols's sense, while the fissure between authenticity and realism in Theirs Is the Glory is unsettling, to say the least, as it simultaneously underwrites and undercuts the truthfulness of the representation. To an extent, it unwittingly foreshadows the self-reflexive mode of "performative documentaries" that reveal their method of production (see: Bruzzi 2001, 153-180; Nichols 2001, 100-138). Yvette Vanson's The Battle for Orgreave (1985) and, more recently, Joshua Oppenheimer's The Act of Killing (2014) fall into this category. Both of these films make use of reenactment by victims and perpetrators respectively but reenactments in these films are supplemented by interviews that prevent characters from slipping into the role of actors. In the mini-series Band of Brothers (2001), each episode starts with interviews of survivors whose stories serve as an inspiration for the story performed by professional actors. In

5 "Muting" characters that enact or reenact scenes for the camera is a strategy of a number of World War II propaganda films, such as the "newsdrama” The Fighting Lady (1944, Steichen), featuring scenes enacted by airmen and seamen in the midst of actual battle, with their voices "hijacked" by an omniscient narrator in free indirect speech. 
the absence of such a scaffold of interviews, Theirs Is the Glory positions itself as a film that features veterans as survivors and actors. This breach between authenticity and realism lays bare the uncanny presence of the past in the form of an emphatic absence that simultaneously reinforces and undermines the rhetorical modes explored in this section. The following section will address this feature of Hurst's film through the pertinent theories of Roland Barthes, Siegfried Kracauer, and Jacques Rancière.

\section{From Reality Effect to Sentence-Image}

In his 1967 essay entitled "The Reality Effect" Barthes focuses on the lengthy descriptions of objects, places, and characters in nineteenth-century realist novels. He identifies these descriptions as typical of the genre and describes their function as an aesthetic expedience on the one hand, and an authenticating device operating as a "referential illusion" on the other. Barthes contends,

The truth of this illusion is this: eliminated from the realist speech-act as a signified of denotation, the 'real' returns to it as a signified of connotation; for just when these details are reputed to denote the real directly, all that they do-without saying so-is signify it; Flaubert's barometer, Michelet's little door finally say nothing but this: we are the real; it is the category of 'the real' (and not its contingent contents) which is then signified; in other words, the very absence of the signified, to the advantage of the referent alone, becomes the very signifier of realism: the reality effect is produced, the basis of that unavowed verisimilitude which forms the aesthetic of all standard works of modernity. $(1986,148)$

The reality effect is thus the result of mistaking connotation for denotation or, in affective terms, perceiving the realistic as authentic. The more meticulous the description, the more it reads as referential to a reality out there. What happens, however, is that the textual coordinates of objects, places, and human characteristics not so much denote the contours of a reality as create an effect of reality at the level of connotation. Barthes's insights into this aspect of the realistic novel also holds true in the domain of film, as Saving Private Ryan (1998, Spielberg), Band of Brothers (2001, various directors), The Pacific (2010, various directors), and, most recently, Fury (2014, Ayer) attest. Whereas these World War II films of the past two decades approximate reality through period-accurate mise-en-scène and superb acting, the reality effect of Theirs Is the Glory lies elsewhere. By making the veterans act out a 
script within the framework of reenactment Hurst creates a tension between what the veterans say as actors and their identity as witnesses. In Barthes's terms, the veterans' bad acting inverses the reality effect by way of allowing the real to return as a signified of denotation, rather than connotation. The veterans do indeed denote the real directly, perhaps too directly, so that their ineptitude as actors foregrounds their identity as survivors and witnesses. This inverse reality effect opens cracks in the fantasmatic world of the story by calling viewers' attention to a reality of the past which the veterans signify existentially, rather than representationally.

In his salient work on film theory Siegfried Kracauer discusses this power of objects, places, and characters to disrupt the narrative flow of film. Similarly to Barthes, he draws on modern realist literature as a forerunner of film's potential to expose minute details of physical reality that "open up a dimension much wider than that of the plots which they sustain" (Kracauer 196o, 303). Kracauer relativizes the secondary status of background to foreground and highlights the defamiliarizing potential of "scattered material events" (1960, 298). "A face on the screen may attract us as a singular manifestation of fear or happiness regardless of the events which motivate its expression. A street serving as the background to some quarrel or love affair may rush to the fore and produce an intoxicating effect," he contends (1960, 303). What is intended to immerse viewers into the story can, paradoxically, open up a dimension "beneath the superstructure of specific story contents" and disengage viewers from the unfolding plot (1960,303). This intoxicating, and no less disorientating, effect is palpable when viewers recognize filming locations as different from what they represent in the film. In Munich (2005, Spielberg), for instance, locations in Budapest are made to stand in for streets in Paris, Berlin, and Munich, making inhabitants of the Hungarian capital literally lose their grip on the plot. By the same token, the bridge at Deventer functioning as Arnhem Bridge in A Bridge Too Far may have been no less confusing for locals. For what these locations say, to twist Barthes's phrase, is that we are not the real but its contingent contents.

The creative potential of this inverse reality effect can best be captured through Jacques Rancière's notion of the sentence-image. Rancière situates the sentence-image in between two regimes of the image: the representative and the aesthetic. In the former, what is visible is put to the service of what is sayable, that is, to an overarching plot or narrative. The latter paradigm subverts this hierarchy by subjecting the sayable to the visible. Similarly to Barthes and Kracauer, he relates this turn to the rise of the nineteenth-century realist novel where the abundance of descriptions of non-signifying details allows what is visible to disrupt what is sayable. Speech "exhibits its particular opacity, the 
under-determined character of its power to 'make visible'... At the same time, however, speech is invaded by a specific property of the visible: its passivity. The performance of speech is struck by this passivity, this inertia of the visible that comes to paralyze action and absorb meanings" (Rancière 2009, 121). Forming a transition between the representative and the aesthetic regimes, the sentence-image is

... the combination of two functions that are to be defined aestheticallythat is, by the way in which they undo the representative relationship between text and image. The text's part in the representative schema was the conceptual linking of actions, while the image's was the supplement of presence that imparted flesh and substance to it. The sentence-image overturns this logic. The sentence-function is still that of linking. But the sentence now links in as much as it is what gives flesh. And this flesh or substance is, paradoxically, that of the great passivity of things without any rationale. (Rancière 2009,46 )

Thus, the sentence-image simultaneously enforces and undermines continuity. It continues to forge causal linkages between narrative constituents but, by the same gesture, it denotatively highlights the materiality of these constituents in Barthes's sense, which, in turn, disrupts meaning-making mechanisms. Unlike the representative system, which turns the visual into the service of the textual, the sentence-image allows for the visual to manifest itself in the "the great passivity of things" that stultifies meaning. The inverse reality effect comes to the fore here in the paradox of the activity of passivity, the overwhelming presence of non-signifying, material details that nevertheless come to bear heavily on the plot-a dynamics Rancière traces in the "vagaries of the indifferent intermixture of atoms" in the novels of Flaubert and Zola, and the "new sensory power of the shots" in the films of Jean Epstein (2009, 43-44). The way in which this dynamics manifests itself in Theirs Is the Glory is discussed in the following section.

\section{"Just Ordinary Men"}

When Lieutenant Ashmore, playing the fictitious Lieutenant Hanbury, appears in the first reenacted scene, he is doubly transformed. First, he is fashioned as an actor. Second, he is to play someone he has never been. His own identity and involvement in Operation Market Garden is concealed in the service of the plot. Other characters, one might say, have gone through less radical 
transformations in the film. Private Peter Holt, along with many other characters, gets to play himself and serves as one of the narrative leads in the film. Upon landing, Holt's parachute is entangled in the crown of a tree, causing him difficulty getting back in touch with his platoon. His fighting alongside different platoons and eventual reunion with his comrades operates as a focalizing device that offers insight into the battle from the perspective of the average soldier. The characters that come closest, at least in particular scenes, to reenact their own roles are Lieutenant Colonel Richard Lonsdale and the Dutch civilian Kate ter Horst, who offered her house to be used as a hospital in the final days of the battle. In one of the most famous scenes of the film Lonsdale delivers a heartwarming speech to his soldiers in the old church at Oosterbeek, shortly before their withdrawal across the Rhine. ${ }^{6}$ Soon after this scene, Kate ter Horst descends to the basement of her house and reads out the 91st Psalm to console the wounded. Although these characters are among those who have the chance to recite what they said a year before, their acting is no more convincing than those impersonating fictitious or real characters.

The juxtaposition of acting and reenacting, and of actors and veterans in Theirs Is the Glory results in a tension that lies at the core of the sentenceimage. The presence of the veterans, as we have seen in the previous section, is key to the authenticity of the reenactment but their clumsy acting undercuts the narrative flow of the film. Such a discrepancy between what they stand for as indexical signs of the film's referent and the realism of their acting suspends the chronological unfolding of events. The sentence-function, in Rancière's sense, is simultaneously present as a cohesive force at the level of the script but is unsettled at the level of acting. While they continue to "play" their roles in the film, this breach unmoors the reenactors from the narrative of the film and allows them to come to the fore as "corporeal remains" of the real campaign. Unhinged from the plot's signifying texture, they gain agency in their passivity, as it were, less as truthful reenactors and more as material imprints of the past. Therefore, the authenticity of the reenactment, emphasized by the opening texts of the film, lies not so much in the action as in what remains unseen by the viewer or, more precisely, what remains "unacted" by the veterans. Rancière's use of the word "flesh" is doubly poignant in this regard. On the one hand, flesh is synonymous with the imposing presence of material details, the non-signifying passivity, which fractures continuity. On the other hand, it

6 Remarkably, Lonsdale's speech was carved into a door to assist him in reciting it. Today the door is on exhibit in the Airborne Museum at Oosterbeek (See: "Oosterbeek-The Old Church"). 
denotes, literally, the body of the veteran as a "material witness" pushed to the fore as a sentence-image in Theirs Is the Glory.

It is unlikely that Hurst was aware of this uncanny potential of his film. The rhetorical modes set in motion at the beginning, as well as his smooth blending of reenactment with newsreel, attest to an effort to represent, rather than deconstruct. Nevertheless, it is hard not to notice how the camera tends to linger on the veterans' eyes that seem to be looking inward, as though immersed in a world outside the plot (Figure 2). Undoubtedly, returning to Arnhem meant more to them than reenacting the events of the previous September. Many of them were looking for the graves of their comrades, bearing witness to the severe losses they had suffered (Travis 1986, 31). If their eyes seem to be looking inward, it is because they contemplate, rather than reenact the past. This is most conspicuous in close-ups showing veterans side-by-side, one engaged in a radio conversation that propels the story forward, while the other remains motionless, waiting it out passively. Rather than revealing the object of their gaze within the narrative, these gazes point back at the agent of looking. What comes to the fore, denotatively, is the character as witness to what Nichols calls the "lost object" that the film approximates through reenactment. The eyes, in their passivity, become direct interfaces between the viewer and the film's referent. For it is through these "passive" gazes that



FIGURE 2 The camera tends to linger on the veterans' eyes that seem to be looking inward, as though immersed in their memories of the battle. Screenshot from Theirs Is the Glory. 
the referent of the reenactment materializes not so much in what is reenacted on the screen but what remains unrepresented yet hauntingly present in the corporeality of the witness. This present absence is precisely what Rancière conceptualizes as an "inertia of the visible that comes to paralyze action and absorb meanings" (Rancière 2009, 121). Bad acting can no longer be regarded as a shortcoming that disrupts the smooth sequence of action. Instead, it is a portal to a dimension that asserts itself through the disruption of action. The film's mise-en-scène reveals further aspects of this dimension.

\section{"Amid the Ruins of Arnhem"}

The "Foreword" of Theirs Is the Glory emphasizes the absence of actors and studio equipment in the making of the film. We have already seen how the veterans' inaptitude as actors recalls their role as witnesses, turning seemingly insignificant gazes and actions into the service of an inverse reality effect, invoking the battle negatively, in the form of absence. Likewise, setting the film in war-torn Arnhem creates a gateway to a past that escapes narrative representation in the film. The inverse reality effect working through the veterans' acting here comes to the fore in a different disguise. The ruins are more than a simple backdrop to the story. They are referenced in the opening texts as the "actual battlefield," imbued with the genius loci unleashed by the reenactment in their midst. No less than the veterans, the ruins are employed to authenticate the reenactment as indexical traces of the real battle. The ruins, however, are not exclusively the result of the battle fought during Operation Market Garden. Due to the failure of the operation the bridge that the First British Airborne was trying desperately to hold was eventually blown up by the German army, delaying the liberation of the city until April 1945 (Travis 1986, 31; Middlebrook 1999). Therefore, the bulk of the ruins visible in the film had been caused by bombardments and sieges over the fall and winter of 1944 (Figure 3).

There is an air of awkwardness about the rudimentary explosions in the midst of buildings wounded by real bombs and bullets and having witnessed real deaths. There is even something irreverent about "playing" war at the site of recent bloodshed. In her eloquent contemplation of artistic representations of ruins Rose Macaulay stipulates that ruins only cater to pleasure (Ruinenlust) once they are far removed from the present and unremembered as sites of pain and loss. In contrast to the aesthetic pleasure that classical ruins afford, new ruins, she contends, "are for a time stark and bare, vegetationless and creatureless; blackened and torn, they smell of fire and 


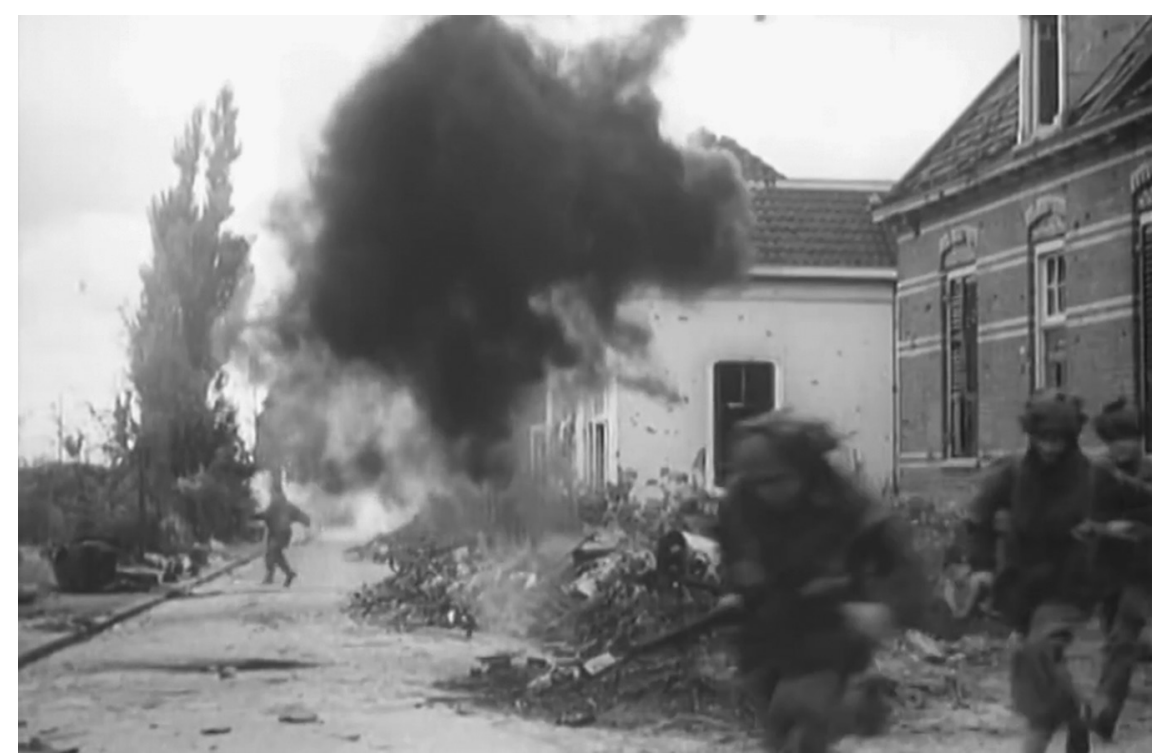

FIGURE 3 Reenacting the Battle of Arnhem among ruins that bear traces of subsequent fighting resulting from the failed operation. Screenshot from Theirs Is the Glory.

mortality" (Macaulay 1953, 453). This kind of ruin is, in Dylan Trigg's term, "traumatized architecture," still exuding the pain of destruction (2009, 94). Playing among the fresh ruins of Arnhem, however, imparts what Nichols calls a "fantasmatic pleasure" played out in a "mise-en-scène of desire" (2008, 76). Reenactment is thus not simply the means to wrap the past into a heroic narrative but also an effort to confront it materially and express the desire to own it. In this sense, besides lending themselves as a rhetorical expedience to authenticate the reenactment, the ruins serve the veterans (and the viewers) as a site not only to reclaim the lost object but also to dramatize its loss. Therefore, if there is a genius loci that emanates from their midst, it is invoked through the effort to bear witness to and work through the past (see: Renov 2004, 120-29).

The scene in which the airborne troops launch their first assault on the bridgehead vividly illustrates this effort. From the perspective of a pathfinder observing the objective of his troops' mission from the remains of a tall building, the bridge becomes visible in the form of a painting on a glass surface that shows it as still intact (Travis 1986, 31) (Figure 4). Subsequently, from the viewpoint of the house where Major "Freddie" Gough establishes his headquarters we again see a painting of the bridge from the West, through the binoculars of a soldier. In this second instance some smoke is visible in the foreground as 


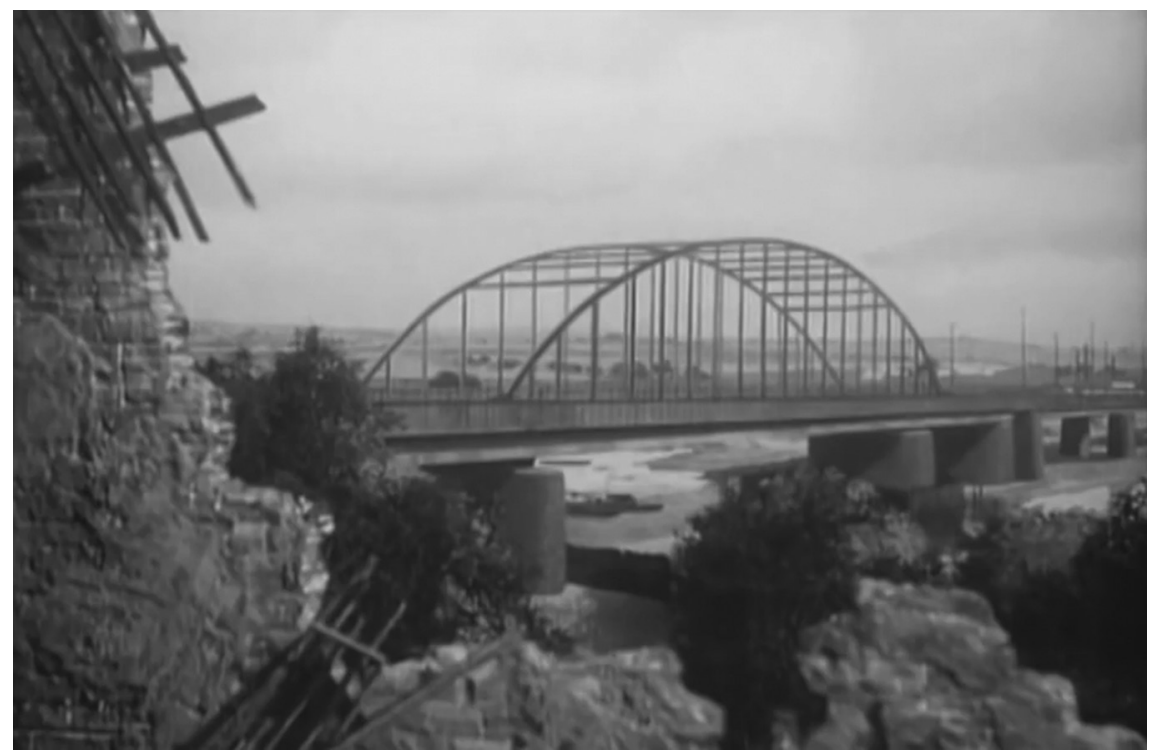

FIGURE 4 Arnhem Bridge painted on a glass surface as though intact. Screenshot from Theirs Is the Glory.

the soldier slowly moves his sight from the bridgehead onto the opposite bank. These painted representations of the bridge make no effort to lull the viewer into a false sense of reality. On the contrary, in the same way that they signify the bridge as intact, they also gesture back to the images of the blown up bridge revealed at the beginning of the film. In doing so, the positioning of the layer of painted glass in front of the camera constitutes a powerful sentence-image. In support of narrative plausibility, the paintings operate as a visual backdrop to the scene, similar to a film set. Concurrently, however, their representational role is suspended by their material palpability as painted glass. This would not necessarily disrupt relational linkages between narrative elements were it not so obvious that the real bridge is no longer there. By way of visually assisting the unfolding of narrative, the paintings uncannily foreshadow a future that, in narrative time, is yet come.

The dynamics of this sentence-image work to map the visible and the sayable onto material, temporal, and affective dimensions. As a substitute, the painted glass operates as a visual corrective. While the transparency of the glass acknowledges the ruined environment as part of the film's narrative, the painting of the bridge becomes indicative of the fetishistic desire to reverse time, of finding pleasure in reimagining the past as one that still holds the possibility of success. 


\section{Conclusion}

This analysis has shown that what the viewer of Theirs Is the Glory may initially perceive as a lack of realism at the level of acting and props is in fact conducive to a kind of reality effect that derives its power from its juxtaposition of authenticity with realism; documentary with feature film; newsreel with reenactment; reenactment with acting; veteran with actor; the sayable with the visible. Indeed, the sentence-image is more than a theoretical term to expose the dynamic collision between these binaries in particular scenes. Janus-faced, it simultaneously connects and disrupts, obscures and illuminates and, as such, it reflects the affective register of the film as a whole. At the same time, rhetorical modes that the film adopts also attest to the attempt to absorb the failure of Operation Market Garden within the narrative of ultimate victory.

The imitation of the Arnhem Bridge on painted glass is an eloquent expression of this effort. A double for the main objective of the operation, the painting signifies its presence at the same instant as it marks its absence. No less awkward than the manner of reenacting the battle itself, the painting is not simply there to substitute but also to fantasize an alternative future in the face of an unchangeable past, to map a wish-image of presence onto the materiality of absence. It is, ultimately, what Nichols describes as the "mise-en-scène of desire." Significantly, the film serves its role as a memorial by focusing on heroism and sacrifice, expressly marked by the soldiers' graves at the beginning of the film and the empty beds in the barracks at the end. The task of pointing the finger of blame at the officers in charge of the campaign would not be taken up until thirty years later by the makers of $A$ Bridge Too Far. To supplement the observation of the contemporary critic of Hurst's film, if the film is known less for its "cinematic virtues" and more for "emotions recalled," one may surmise that it is precisely in the lack of those virtues that emotions are most complexly palpable.

\section{Bibliography}

Austin, J.L. 1962. How To Do Things With Words. Oxford: Clarendon Press.

Barthes, Roland. 1986. The Rustle of Language. Translated by Richard Howard. New York: Hill and Wang.

Bruzzi, Stella. 2001. New Documentary: A Critical Introduction. London and New York: Routledge.

Hughes, Howard. 2012. When Eagles Dared: The Filmgoers' History of World War II. London: I.B. Tauris. 
Hurst, Brian Desmond. 1946. Theirs Is the Glory. Distributed by DD Home Entertainment, 2004. DVD.

K.F.B. Review of Theirs Is the Glory. Monthly Film Bulletin (January 1, 1946): 135 .

Kracauer, Siegfried. 196o. Film Theory: The Redemption of Physical Reality. New York: Oxford University Press.

Lloyd, Christopher. Review of Theirs Is the Glory. The Film Yap (January 16, 2014). Accessed May 16, 2016. http://www.thefilmyap.com/movies/theirs-is-the -glory-1946/

Macaulay, Rose. 1953. Pleasure of Ruins. New York: Walker and Company.

Middlebrook, Martin. 1999. Arnhem 1944: The Airborne Battle 17-16 September. London: Penguin.

Nichols, Bill. 2001. Introduction to Documentary. Bloomington: Indiana University Press.

Nichols, Bill. 2008. "Documentary Reenactment and the Fantasmatic Subject." Critical Inquiry 35: 74 .

"Oosterbeek-The Old Church." Airborne Assault Paradata: The Living History of the Parachute Regiment And Airborne Forces. Accessed May 16, 2016. http://www.paradata .org.uk/content/oosterbeek-old-church

Peirce, Charles Sanders. 1955. "Logic as Semiotics: The Theory of Signs." In Philosophical Writings of Peirce, edited by Justus Buchler, 98-119. New York: Dover.

Rancière, Jacques. 2009. The Future of the Image. Translated by Gregory Elliott. London and New York: Verso.

Renov, Michael. 2004. The Subject of Documentary. Minneapolis: University of Minnesota Press.

Schneider, Rebecca. 2011. Performing Remains: Art and War in Times of Theatrical Reenactment. New York: Routledge.

Smith, Allan Esher. 2010. "Theirs Is the Glory (1946)." Brian Desmond Hurst. Accessed May 16, 2016. http://www.briandesmondhurst.org/theirsistheglory.html

Travis, William B. 1986. "Theirs Is the Glory." After the Battle 58: 32-44.

Theirs Is the Glory. Directed by Brian Desmond Hurst. 1946. Strawberry Media Limited, 2014. DVD.

Trigg, Dylan. 20og. "The Place of Trauma: Memory, Hauntings, and the Temporality of Ruins." Memory Studies 2 (87): 94. 